\title{
Monitoring of Proximate Composition, Heavy Metal Concentrations and Pesticide Residues in Marine Dried Fish Available in the Coastal Region of Bangladesh
}

\author{
Mousumi Kar', Md. Enamul Hoq², Md. Sirajul Islam ${ }^{1 *}$, Md. Monirul Islam³, \\ Nowara Tamanna Meghla ${ }^{1}$, Suravi ${ }^{1}$, Md. Humayun Kabir ${ }^{1}$ \\ ${ }^{1}$ Department of Environmental Science and Resource Management, Mawlana Bhashani Science and \\ Technology University, Tangail-1902, Bangladesh \\ ${ }^{2}$ Research Planning \& Evaluation Division, Bangladesh Fisheries Research Institute, Mymensingh-2201, Bangladesh \\ ${ }^{3}$ Nutrition Division, Bangladesh Agricultural Research Council, Dhaka-1215, Bangladesh \\ *Corresponding author (Email: islammstazu@yahoo.com)| ORCID: 0000-0002-7560-9334
}

How to cite this paper: Kar, M., Hoq, M.E., Islam, M.S., Islam, M.M., Meghla, N.T., Suravi, and Kabir, M.H. (2020). Monitoring of Proximate Composition, Heavy Metal Concentrations and Pesticide Residues in Marine Fish Available in the Coastal Region of Bangladesh. Grassroots Journal of Natural Resources, 3(2): 30-41. Doi: https://doi.org/10.33002/nr2581.6853.03023

Received: 12 May 2020

Reviewed: 23 May 2020

Provisionally Accepted: 25 May 2020

Revised: 31 May 2020

Finally Accepted: 15 June 2020

Published: 22 June 2020

Copyright (C) 2020 by author(s)

This work is licensed under the Creative Commons Attribution International License (CC BY 4.0). http://creativecommons.org/licenses/by/4.0/

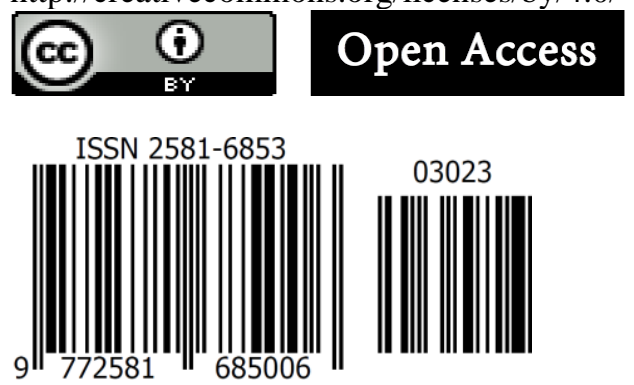

\section{Abstract}

The study for this paper was conducted to assess the proximate compositions, heavy metal concentrations and pesticide residues in marine dried fish. The selected fish were silver pomfret (Pampus chinensis), bombay duck (Harpadon nehereus), ribbon fish (Trichiurus savala), sardine (Salmostona bacaila) and anchovy (Colia dussumieri) collected from the Cox's Bazar, Kuakata (Patuakhali) and Dubla Island (Khulna) of Bangladesh coast. The moisture content ranged from $11.27 \%$ (S. bacaila) to $38.94 \%$ ( $P$. chinensis) among the dried fish products. Protein content varied from $51.33 \%$ (C. dussumieri) to $77.68 \%$ ( $T$. savala). The As concentration varied from $8.41 \mathrm{mg} / \mathrm{kg}$ to $22.27 \mathrm{mg} / \mathrm{kg}$ only in $T$. savala. The Fe content was measured 116.85 $\mathrm{mg} / \mathrm{kg}$ to $160.18 \mathrm{mg} / \mathrm{kg}$ in $H$. nehereus and $P$. chinensis. The $\mathrm{Zn}$ concentration varied from $31.08 \mathrm{mg} / \mathrm{kg}$ to $36.74 \mathrm{mg} / \mathrm{kg}$. Among heavy metals, As, Fe and $\mathrm{Zn}$ concentration were found higher than the permissible level for human consumption. However, $\mathrm{Cd}, \mathrm{Cu}$ and $\mathrm{Pb}$ tested were found within the permissible level in all three species. The residue of organochlorine pesticide was found within the maximum residue limit level recommended by World Health Organization. The existence of pesticides residues in the samples of this study is a matter of health concern as this poisoning has long term effect on human health.

\section{Keywords}

Marine dried fish, Proximate compositions, Heavy metals, Pesticide residues 
Doi: https://doi.org/10.33002/nr2581.6853.03023

\section{Introduction}

The fisheries sector of Bangladesh contributed to the country's GNP amounting about $4.4 \%$ of the total GDP and the seafood export sector is now the country's second largest source of foreign exchange (DoF, 2012). The marine and coastal capture fishery is a primary source of income and nutrition for over 484,000 households in the coastal region. In terms of nutrition, aquatic resources of Bangladesh are reported to meet more than $60 \%$ of the country's animal protein, and a critical source of essential minerals, vitamins and fatty acids comes from fish and fish products. Fish is an extremely perishable food item and requires preservation for future uses. In Bangladesh, fish drying is mainly concentrated in the coastal districts i.e. Cox's Bazar, Chittagong, Patuakhali, Khulna, and, especially, in the hoar and beel areas of Bangladesh (DoF, 2012).

The sun drying of fish is the most common and the oldest known method of preservation, which has been widely used in coastal Bangladesh during the period of mid-October to mid-April. During this period the coastal crisscross channels and other depressions remain calm and quiet leading to harvesting of huge amount of fish (Bhuiyan, Bhuiyan and Nath, 2009). About 7\% of total fish production in Bangladesh is dried for local consumption and export (Belton et al., 2014). The common marine dry fish in Bangladesh includes ribbonfish, Bombay duck, croaker, silver pomfret, shrimp, etc. (Bhuiyan et al., 2008).

Unexpectedly and usually the fishermen do not dry the fish properly due to loss of weight as they want more profit by selling the dry fish. On the other hand, sufficient drying cannot be achieved during the bad weather or rainy season using the traditional sun drying methods. In such conditions, due to high moisture content in the weather, the stored dried fish are susceptible to insects and microorganisms (Chowdhury et al., 2010). To avoid infestation and for safe storage, dried fish producers often apply various types of pesticides including organochlorine in the raw material or dried products (Bhuiyan et al., 2008; Chowdhury et al., 2010; Siddique and Akter, 2012). The inappropriate drying and applying pesticides on dried fish are two malpractices that have adverse effects on flavor, taste and texture of dried fish. Another major concerning issue nowadays is the presence of heavy metals in fish and fish products.

Heavy metal pollutants such as arsenic, mercury and cadmium together with insecticides were discharged from the ambient industrial environment into the water body which causes contamination of the aquatic environment. Heavy metals are mostly taken up by fish directly from water but may also be ingested substantially from contaminated food (Atuanya, Edefetah and Nwogu, 2011). These natural occurring metals are toxic at very low level and have long term exposure results in human health. Although many researches have been conducted on heavy metals in fish, there seems to be inadequate literature on heavy metals in dried fish sold in the market. In view of these circumstances, the present study was carried out to assess proximate composition, heavy metal concentrations and concentration of pesticide residues in marine dried fish collected from three different fish drying areas as Cox's Bazar, Kuakata (Patuakhali) and Dubla Island (Khulna) of Bangladesh coast.

\section{Materials and Methods}

Study area: The study areas were coastal districts of Khulna (Dubla Island), Patuakhali (Kuakata) and Cox's Bazar, which are the main marine dried fish production sites in Bangladesh. The coastal 
area is affected with various ways by its closeness to the sea together with the human activities from the land. The Dubla Island of Khulna division is located in the southwestern of Bangladesh between $22^{\circ} 5^{\prime} \mathrm{N}$ to $89^{\circ} 15^{\circ} \mathrm{E}$. The Kuakata of Patuakhali district is also located in the southwest part of Bangladesh between $22.3542^{\circ} \mathrm{N}$ to $90.3181^{\circ} \mathrm{E}$. Cox's Bazar is situated in the southeastern region of Bangladesh between $21.4500^{\circ} \mathrm{N}$ to $91.9833^{\circ} \mathrm{E}$ (Figure 1).

Sample collection: Dried fish samples of six different species namely silver pomfret (rupchanda, Pampus chinensis), Bombay duck (loittya, Harpadon nehereus), ribbon fish (churi, Trichiurus savala), sardine (ichari, Salmostona bacaila), and anchovy (phasa, Setipinna phasa; olua, Colia dussumieri) were collected from three coastal locations as explained above, i.e. Khulna (Dubla Island), Patuakhali (Kuakata) and Cox's Bazar. However, three most popular dry fish samples loittya, churi and rupchanda were used for heavy metals and pesticide residues determination. Dried fish were collected randomly from the local markets during winter months (December to February).

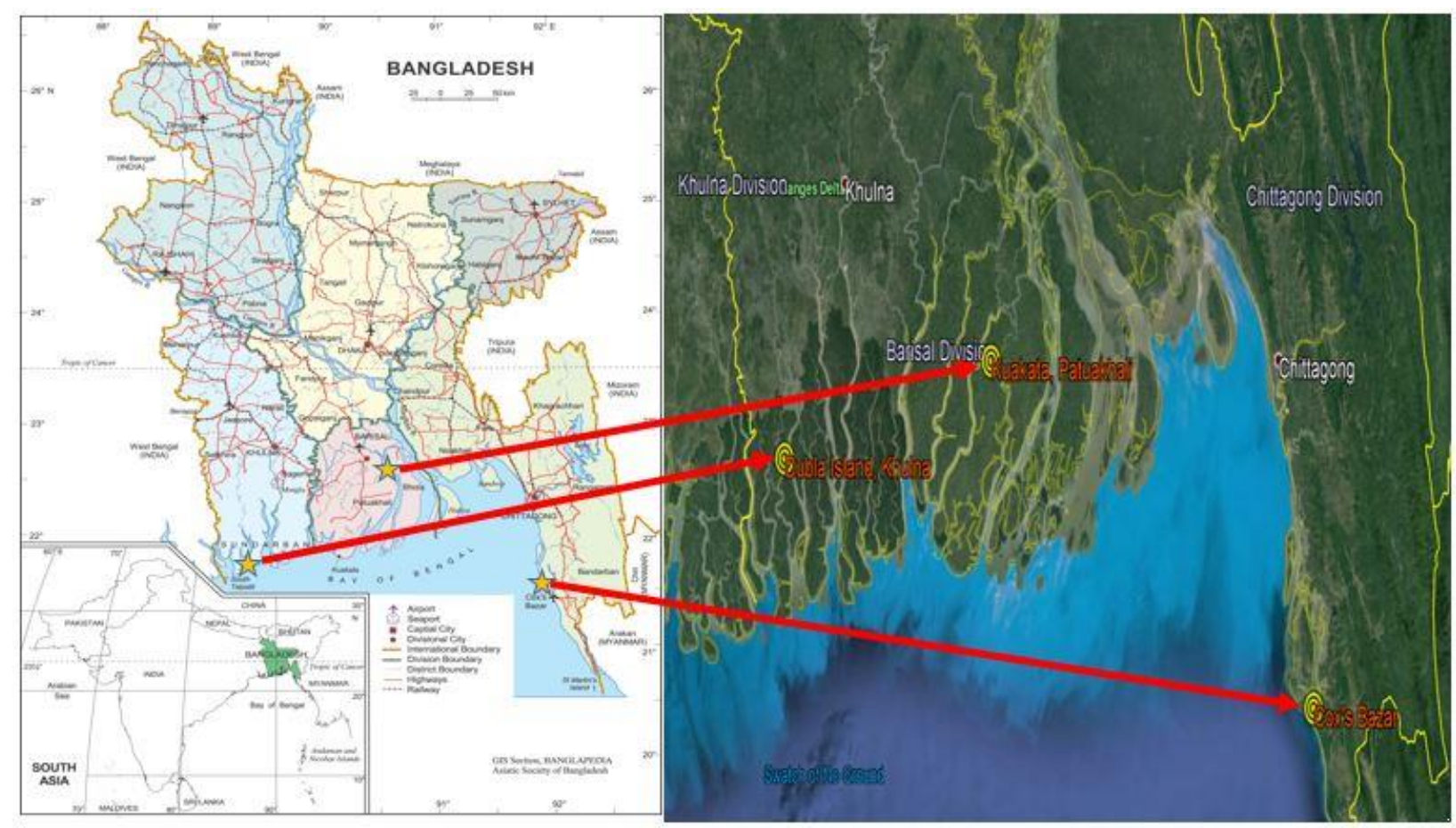

Figure 1: Map showing the study area in Khulna, Patuakhali and Cox's Bazar coastal region

Sample preparation and analysis: A sample of $200 \mathrm{~g}$ dried fish for each species marketed recently from production cycle was collected and kept individually in polyethylene bag following the procedure described by Siddique and Akter (2011). Then the samples were transported to the Fish Nutrition Laboratory of Bangladesh Fisheries Research Institute, Mymensingh for proximate composition analysis. Heavy metal and pesticide residues analysis were done in Food Laboratory of SGS Bangladesh Limited in Dhaka.

Proximate composition: For the proximate composition analysis, sample was taken accurately, and each sample was crushed by mortar and pestle. The samples were analyzed for moisture, ash, 
protein and lipid. In each case, three replicates were maintained. Proximate composition was carried out following the methods of AOAC (1995).

Heavy metal concentrations: To determine the heavy metals i.e. Arsenic (As), Cadmium (Cd), Copper $(\mathrm{Cu})$, Iron $(\mathrm{Fe})$, Lead $(\mathrm{Pb})$ and Zinc $(\mathrm{Zn})$, the samples were digested and poured to digestion tubes. The samples were put in a water bath set to boiling temperature of $100^{\circ} \mathrm{C}$ and boiled for about 2 hours until all the tissues were dissolved. The digests were allowed to cool, were filtered, and were transferred to $25 \mathrm{ml}$ volumetric flasks to make up to mark with $1 \%$ nitric acid. The digests were kept in plastic bottles. The heavy metal concentrations in samples were determined using a Flame Atomic Absorption Spectrophotometer (Model AA-6300, Shimadzu, Japan). All samples were estimated in $\mathrm{mg} / \mathrm{kg}$ with triplicate reading.

Pesticide concentrations: The DDT and heptachlor residues were analyzed by GC (Gas Chromatograph-14B, Shimadzu, Japan) with an electron capture detector (ECD) following Bhuiyan, Bhuiyan and Nath (2009). A column of $3.1 \mathrm{~m}$ x $3.2 \mathrm{~mm}$ having ID glass spiral, stationary phase silicon OV-17, 5\% aging $300^{\circ} \mathrm{C}$, support chromosorb-W-AWDMCS, mesh 80/100, and 1 $\mu \mathrm{m}$ film thickness was used for the chromatographic separation of pesticides. The temperature was fixed for the injector at $250^{\circ} \mathrm{C}$, column at $280^{\circ} \mathrm{C}$, and detector at $280^{\circ} \mathrm{C}$. The carrier gas was nitrogen with a $60 \mathrm{ml} / \mathrm{min}$-flow rate. $1.0 \mathrm{ml}$ sample was injected for each run and the running time was 25 minutes. Standards' peaks were identified by injecting high concentration of standard $(0.5$ ppm and $0.25 \mathrm{ppm}$ ) and the retention time for DDT and heptachlor were determined. Then calibration was done at 3 points ( $25 \mathrm{ppb}, 50 \mathrm{ppb}$ and $100 \mathrm{ppb}$ ) by composite stock standard solution. The GC system was calibrated using external standard technique. Individual standard stock solution $(100 \mathrm{mg} / \mathrm{L})$ was prepared by weighing appropriate amounts of active ingredients in a brown bottle with a Teflon-lined screw cap and dissolving the weighed standard in HPLC (High Performance Liquid Chromatography) grade hexane. Stock standard solution was used to prepare primary dilution standards. Appropriate volume of each stock solution was taken in a volumetric flask and mixed the solutions to obtain composite stock standard solution.

\section{Results and Discussion}

Drying of marine fish is widespread in the entire coastal areas of Bangladesh and these dried fish have demand both in domestic and international markets. The people involved early in the production chain (fishing and drying) add relatively little value and make small profit (Figure 2). This less value addition at small-scale producer level is presumed to be the reason of poor product quality and lack of market access due to various institutional and non-institutional barriers (DoF, 2012).

\section{Proximate composition in marine dried fish}

The proximate compositions are important parameters of fish quality assessment, which influence the nutritive value, quality, functional properties and sensory properties of fish. Proximate compositions i.e. moisture, ash, total lipid and crude protein contents of six dried fish product samples from three different locations, are presented in Table 1.

Moisture content: The moisture content of dried fish products varied from species to species and location to location. The highest moisture content was found in all the samples collected from 
Doi: https://doi.org/10.33002/nr2581.6853.03023

Cox's Bazar and its values ranged from $18.04 \%$ to $38.94 \%$ (Table 1). In contrast, the lowest moisture content was measured in the samples of Dubla Island, Khulna which varied from 11.27\% to $20.01 \%$. However, the corresponding values were placed in intermediate position for all dried samples collected from Kuakata, Patuakhali. The highest moisture content was measured in silver pomfret samples (38.94\%) obtained from Cox's Bazar, while the lowest corresponding value was found in sardine samples collected from Dubla (11.27\%). The nutritional composition may vary considerably with season and catching areas and also varied in large scale in different dried fish products (Flowra et al., 2012). The moisture content of three dried marine fish (Harpodon nehereus, Johnius dussumieri and Trichiurus savala) varied from $13.81 \%$ to $22.22 \%$ (Siddique and
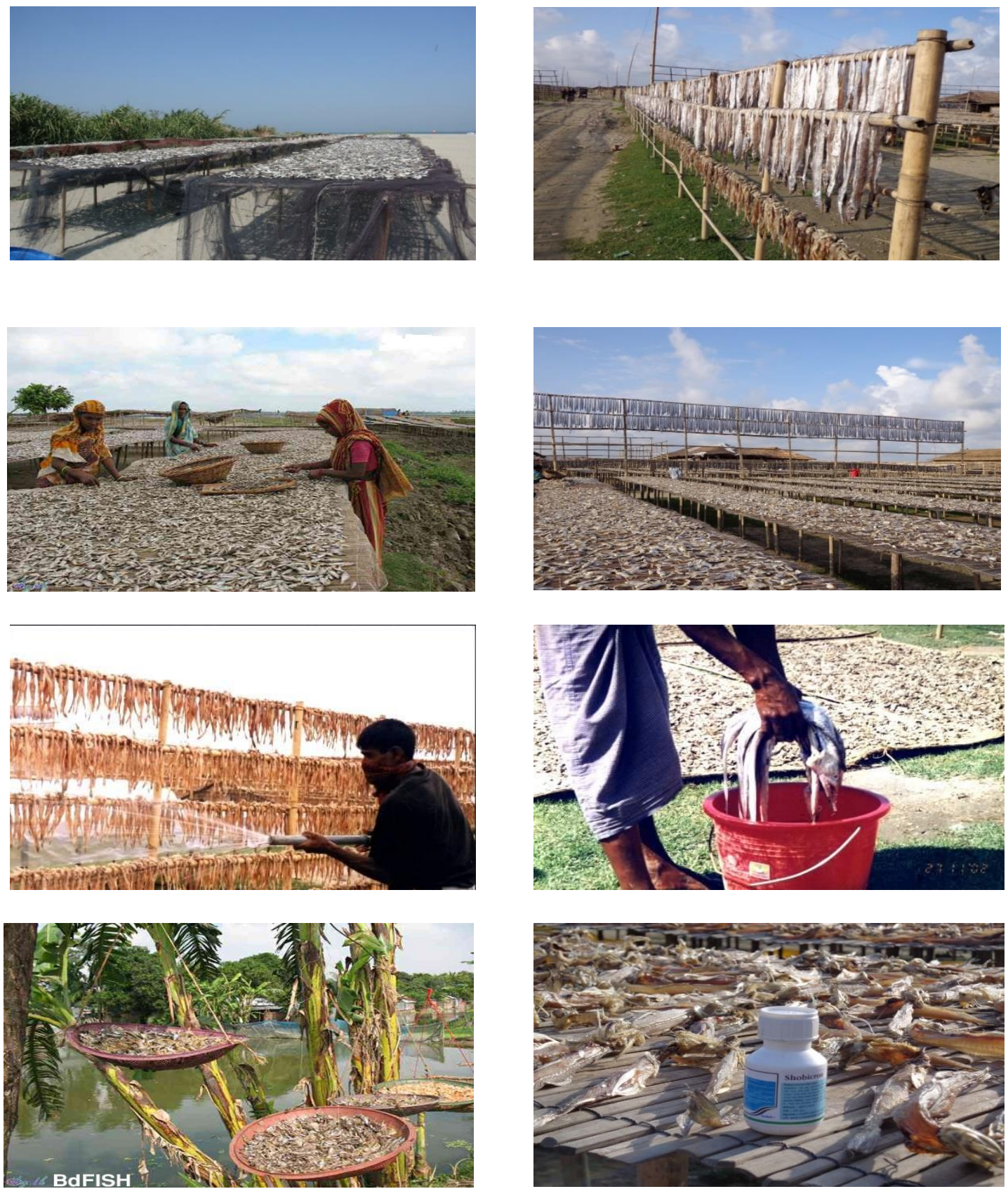

Figure 2: A view of the marine fish drying oldest methods in the coastal region of Bangladesh 
Akter, 2011) in the samples from Dubla, but lower than the value of samples from Cox's Bazar. Relative low moisture content of $6.9 \%$ to $14.2 \%$ was reported in dried marine fish of Bangladesh (Bhuiyan, 1992). For the species of fish considered, season of drying and storage time are the contributing factors for the deviations noted.

Ash content: The ash content varied greatly among the dried fish samples of three different locations. The highest content was found in all samples collected from Cox's Bazar where the values varied from $21.52 \%$ to $34.16 \%$ (Table 1). Conversely, the ash contents ranged from $6.18 \%$ to $20.88 \%$ in the samples of Dubla. Ash content in dried marine fish ranged between $4.86 \%$ and 7.56\% (Siddique and Akter, 2012) and between 6.6\% and 16.2\% (Bhuiyan, 1992). All these measurements reported are quite low as compared to the present investigation.

Total lipid: Likewise, the higher lipid content was measured in dried fish species collected from Cox's Bazar than the samples collected from Kuakata and Dubla. The highest lipid content was found in silver pomfret (27.74\%) of Cox's Bazar and the lowest was in ribbon fish $(3.59 \%)$ of Dubla (Table 1). Lipid content ranged from $0.45 \%$ to $15.51 \%$ in marine fish (Rubbi et al., 1987). The mean percentages of lipid contents in three types of marine dry fish samples varied from 5.54\% to $7.79 \%$ (Siddique and Akter, 2012) and lipid content varied from $6.84 \%$ to $9.21 \%$ in dried marine fish (Bhuiyan, 1992). Variation in lipid content was influenced by the variation of species, diet, temperature, salinity, selective mobilization and distribution (Lovern, 1950).

Table 1: Proximate composition of marine dried fish from Bangladesh coast

\begin{tabular}{llccc}
\hline Marine dried fish & $\begin{array}{l}\text { Proximate } \\
\text { composition }\end{array}$ & $\begin{array}{c}\text { Cox's } \\
\text { Bazar }\end{array}$ & $\begin{array}{c}\text { Kuakata } \\
\text { (Patuakhali) }\end{array}$ & $\begin{array}{c}\text { Dubla } \\
\text { Island } \\
\text { (Khulna) }\end{array}$ \\
\hline Silver pomfret (Pampus chinensis) & Moisture & 38.94 & 32.59 & 14.69 \\
& Ash & 26.01 & 26.76 & 6.18 \\
& Total Lipid & 27.74 & 22.85 & 17.35 \\
& Crude Protein & 55.90 & 54.26 & 52.82 \\
\hline Bombay duck (Harpadon nehereus) & Moisture & 26.01 & 23.09 & 20.01 \\
& Ash & 27.60 & 25.38 & 15.41 \\
& Total Lipid & 10.04 & 10.04 & 10.60 \\
& Crude Protein & 69.42 & 65.47 & 69.54 \\
\hline Ribbon fish (Trichiurus savala) & Moisture & 27.13 & 20.76 & 12.53 \\
& Ash & 21.52 & 6.37 & 8.02 \\
& Total Lipid & 7.74 & 5.54 & 3.59 \\
& Crude Protein & 65.42 & 63.39 & 77.68 \\
\hline Sardine (Salmostona bacaila) & Moisture & 27.42 & 15.62 & 11.27 \\
& Ash & 34.16 & 26.76 & 11.89 \\
& Total Lipid & 23.83 & 23.73 & 13.73 \\
& Crude Protein & 58.94 & 58.78 & 71.52 \\
\hline Anchovy (Setipinna phasa) & Moisture & 23.49 & 18.92 & 18.92 \\
& Ash & 24.83 & 24.09 & 24.09 \\
& Total Lipid & 6.22 & 21.32 & 21.32 \\
& Crude Protein & 62.98 & 57.74 & 57.74 \\
\hline Anchovy (Colia dussumieri) & Moisture & 18.04 & 13.76 & 14.16
\end{tabular}


Doi: https://doi.org/10.33002/nr2581.6853.03023

\begin{tabular}{lccc} 
Ash & 31.37 & 25.61 & 20.88 \\
Total Lipid & 4.74 & 12.88 & 9.27 \\
Crude Protein & 51.33 & 67.80 & 69.47 \\
\hline
\end{tabular}

Crude protein: The crude protein content varied from $51.33 \%$ to $77.68 \%$ among the six different dried fish species. The highest protein percentage was found in ribbon fish collected from Dubla while the lowest value was found in dried olua sample collected from Cox's Bazar (Table 1). The protein content was relatively higher in the fish samples of Dubla as compared to other two locations (Kuakata and Cox's Bazar). Protein content ranged between $58.33 \%$ and $71.90 \%$ in dried marine fish of Bangladesh (Siddique and Akter, 2011).

\section{Heavy metal concentrations in marine dried fish}

Fish is one of the most important food sources. Thus, intake of trace elements via capture fish, particularly toxic elements, is one of the concerns for human health (Ahmad and Othman, 2010). The mean concentration (mg/kg) of six heavy metals ( $\mathrm{As}, \mathrm{Cd}, \mathrm{Cu}, \mathrm{Fe}, \mathrm{Pb}$ and $\mathrm{Zn}$ ) in three dried marine fish species are presented in Table 2. The As concentration in ribbon fish of Cox's Bazar $(22.27 \mathrm{mg} / \mathrm{kg}$ ) and Dubla $(8.41 \mathrm{mg} / \mathrm{kg})$ was found higher than the permissible level of $7.5 \mathrm{mg} / \mathrm{kg}$ set by FAO (1983). The iron (Fe) content was found relatively higher in Bombay duck across all samples of three locations, which varied between $116.85 \mathrm{mg} / \mathrm{kg}$ to $160.18 \mathrm{mg} / \mathrm{kg}$. Further, it was also found higher iron content than the permissible level in silver pomfret $(146.83 \mathrm{mg} / \mathrm{kg}) \mathrm{sample}$ obtained from Dubla. The $\mathrm{Zn}$ concentration also crossed the permissible limit $(30 \mathrm{mg} / \mathrm{kg})$ in all three species only for one location in each species and the value varied from $31.08 \mathrm{mg} / \mathrm{kg}$ to 36.74 $\mathrm{mg} / \mathrm{kg}$. However, other three metals analyzed i.e. cadmium $(\mathrm{Cd})$, copper $(\mathrm{Cu})$ and lead $(\mathrm{Pb})$ were found within the permissible level in all three species across the study locations.

The concentration of $\mathrm{Pb}, \mathrm{Zn}$ and $\mathrm{Fe}$ in freshwater dried fishes i.e. Sarotherodon galilaues, Cyprinus carpio, Clarias gariepinus, Sardinella sp. and Labeo sp. were recorded $0.64 \mathrm{mg} / \mathrm{kg}, 79.06 \mathrm{mg} / \mathrm{kg}$ and $621.61 \mathrm{mg} / \mathrm{kg}$, respectively (Table 2), which were within the permissible limit (Ako and Salihu, 2004). It is also notable that heavy metals in fish depend on the factors such as environmental pollution, type of fish species, microflora of aquatic environment, age of fish, biological and physical processes in aquatic environment, and handling and storage processes (Clearwater, Farag and Meyer, 2002).

The lead $(\mathrm{Pb})$ is highly toxic to aquatic organisms, especially, to fish (Rompala, Rutosky and Putnam, 1984). Copper is an essential metal for number of enzymes, and also higher levels of copper lead to toxic effects on biota. In the present study, the results show that the average concentration of copper in dried fish varied from $0.23 \mathrm{mg} / \mathrm{kg}$ to $0.99 \mathrm{mg} / \mathrm{kg}$ (Table 2), which is much lower than the permissible limit set by FAO/WHO (1984). Cadmium is toxic element which shows its carcinogenic effect on aquatic biota and human. In the present study, no Cd was detected in the dried fish samples. The increasing demand for food safety has accelerated research regarding the risks associated with consumption of food contaminated by heavy metal (Mansour et al., 2009). Entry of metal into food chain is considerably harmful for human health and the environment because of their high toxicity (Olowu et al., 2010). Most studies conducted on fish revealed that muscles accumulate the lowest concentration of metals as compared to liver, kidney and fin. Copper and chromium in fish muscles show increasing tendency with fish age, the accumulation of metals in fish is as a result of accumulation of these metals from water body during scale 
formation (Rashed, 2001). Other factors such as effluent from industries, pharmaceuticals and other pollution sources tend to contribute to high level of metals in fish (Chatterjee, Bhattacharya and Das, 2001). It was found that the zinc in comparison with other element tends to concentrate more in the muscles of fish during post-harvest processing (Yi, Yang and Zhang, 2011). Furthermore, ecological factors such as seasons, grow out area, nutrient availability, temperature and salinity of the water may contribute to the inconsistency of metals concentration in fish tissue (Tüzen, 2003).

Table 2: Heavy metal concentration in marine dried fish from Bangladesh coast

\begin{tabular}{|c|c|c|c|c|c|}
\hline Marine dried fish & $\begin{array}{l}\text { Heavy metals } \\
(\mathrm{mg} / \mathrm{kg})\end{array}$ & $\begin{array}{l}\text { Cox's } \\
\text { Bazar }\end{array}$ & $\begin{array}{c}\text { Kuakata } \\
\text { (Patuakhali) }\end{array}$ & $\begin{array}{c}\text { Dubla } \\
\text { Island } \\
\text { (Khulna) }\end{array}$ & $\begin{array}{c}\text { Permissible } \\
\text { level }\end{array}$ \\
\hline \multicolumn{6}{|c|}{ Silver pomfret (Pampus chinensis) } \\
\hline & As & 1.63 & 1.47 & 3.21 & 7.5 \\
\hline & $\mathrm{Cd}$ & ND & ND & ND & 0.50 \\
\hline & $\mathrm{Cu}$ & 0.23 & 0.30 & 0.84 & 30 \\
\hline & $\mathrm{Fe}$ & 37.31 & 66.67 & 146.83 & 100 \\
\hline & $\mathrm{Pb}$ & 0.009 & 0.32 & 0.29 & 0.30 \\
\hline & $\mathrm{Zn}$ & 20.49 & 16.95 & 46.42 & 30 \\
\hline \multicolumn{6}{|c|}{ Bombay duck (Harpadon nehereus) } \\
\hline & As & 1.46 & 2.31 & 1.67 & 7.5 \\
\hline & $\mathrm{Cd}$ & ND & ND & 0.001 & 0.50 \\
\hline & $\mathrm{Cu}$ & 0.57 & 0.68 & 0.51 & 30 \\
\hline & $\mathrm{Fe}$ & 116.85 & 153.08 & 160.18 & 100 \\
\hline & $\mathrm{Pb}$ & 0.03 & 0.12 & 0.23 & 0.30 \\
\hline & $\mathrm{Zn}$ & 28.02 & 31.08 & 28.60 & 30 \\
\hline \multicolumn{6}{|c|}{ Ribbon fish (Trichiurus savala) } \\
\hline & As & 22.27 & 0.95 & 8.41 & 7.5 \\
\hline & $\mathrm{Cd}$ & ND & ND & ND & 0.50 \\
\hline & $\mathrm{Cu}$ & 0.99 & 0.57 & 0.84 & 30 \\
\hline & $\mathrm{Fe}$ & 36.04 & 48.03 & 61.34 & 100 \\
\hline & $\mathrm{Pb}$ & 0.05 & 0.013 & ND & 0.30 \\
\hline & $\mathrm{Zn}$ & 36.74 & 24.91 & 27.57 & 30 \\
\hline
\end{tabular}

Note: $*$ FAO (1983), ND = Not Detected.

The zinc was found to be the most abundant heavy metal contaminant in the dried fish samples obtained from the market and the high level of some other toxic metals, such as $\mathrm{As}, \mathrm{Pb}$ and $\mathrm{Fe}$, above the permissible limit of FAO, indicated unsafe for fish product. So, the constant buildup of the metal contaminants can be checked if relevant government agencies ensure strict environmental compliance of industry standards which should ensure treatment of industrial effluent before discharging into open water system.

\section{Pesticide residues in marine dried fish}

The concentration of different pesticide residues in the dried fish species from three sampling sites was presented in Table 3. Except for DDT, the concentration of all pesticide residues was found less than $0.01 \mathrm{mg} / \mathrm{kg}$ in dried fish across all three locations. However, the DDT residue was 
estimated to be $0.01 \mathrm{mg} / \mathrm{kg}$ in all dried species samples collected from Kuakata and Dubla, whereas it was less than $0.01 \mathrm{mg} / \mathrm{kg}$ in the samples of Cox's Bazar. The concentration of total DDT in commercially produced sun-dried freshwater fish species samples ranged from $0.094 \mathrm{mg} / \mathrm{kg}$ to $11.88 \mathrm{mg} / \mathrm{kg}$ (Chowdhury et al., 2010).

Furthermore, all other pesticide residues in the analyzed samples remained below the MRL (maximum residue limit) level. The mean concentrations of DDT in the samples of ribbon fish, Bombay duck and croaker were ranged between $130.85 \mathrm{ppb}$ to $153.47 \mathrm{ppb}, 125.21 \mathrm{ppb}$ to 181.4 ppb and $119.86 \mathrm{ppb}$ to $208.65 \mathrm{ppb}$, respectively (Siddique and Aktar, 2012). The DDT used in the samples of ribbon fish, shrimp and Bombay duck was $3.038 \mathrm{ppb}$ to $874.966 \mathrm{ppb}$ from markets of Dhaka and Chittagong (Bhuiyan et al., 2008). In another study, the DDT concentration at winter was found $5.588 \mathrm{ppb}$ to $250.758 \mathrm{ppb}$ and at rainy season concentration ranged from $11.054 \mathrm{ppb}$ to 1107.427 ppb in Bombay duck, ribbon fish, shrimp, hilsha, Chinese pomfret and Indian salmon (Bhuiyan, Bhuiyan and Nath, 2009).

Table 3: Pesticide residues in marine dried fish from the Bangladesh coast

\begin{tabular}{|c|c|c|c|c|}
\hline Marine dried fish & Pesticides (mg/kg) & Cox's Bazar & $\begin{array}{c}\text { Kuakata } \\
\text { (Patuakhali) }\end{array}$ & $\begin{array}{c}\text { Dubla Island } \\
\text { (Khulna) }\end{array}$ \\
\hline \multicolumn{5}{|c|}{ Silver pomfret (Pampus chinensis) } \\
\hline & Heptachlor & $<0.01$ & $<0.01$ & $<0.01$ \\
\hline & DDT & $<0.01$ & 0.01 & 0.01 \\
\hline & Aldrin & $<0.01$ & $<0.01$ & $<0.01$ \\
\hline & Dieldrin & $<0.01$ & $<0.01$ & $<0.01$ \\
\hline & Hexachlorobenzene & $<0.01$ & $<0.01$ & $<0.01$ \\
\hline \multicolumn{5}{|c|}{ Bombay duck (Harpadon nehereus) } \\
\hline & Heptachlor & $<0.01$ & $<0.01$ & $<0.01$ \\
\hline & DDT & $<0.01$ & 0.01 & 0.01 \\
\hline & Aldrin & $<0.01$ & $<0.01$ & $<0.01$ \\
\hline & Dieldrin & $<0.01$ & $<0.01$ & $<0.01$ \\
\hline & Hexachlorobenzene & $<0.01$ & $<0.01$ & $<0.01$ \\
\hline \multicolumn{5}{|c|}{ Ribbon fish (Trichiurus savala) } \\
\hline & Heptachlor & $<0.01$ & $<0.01$ & $<0.01$ \\
\hline & DDT & $<0.01$ & $<0.01$ & 0.01 \\
\hline & Aldrin & $<0.01$ & $<0.01$ & $<0.01$ \\
\hline & Dieldrin & $<0.01$ & $<0.01$ & $<0.01$ \\
\hline & Hexachlorobenzene & $<0.01$ & $<0.01$ & $<0.01$ \\
\hline
\end{tabular}

Some previous studies as well as the present investigation revealed the presence of organochlorine insecticides (DDT and heptachlor) in almost all marine dried fish which may cause chronic disease and have potential long-term risk for human health (Table 3). For protection of dry fish from infestation, the fishermen use insecticides. Pesticides in dry fish may be attributed to (i) accumulation from environment of the respective fish or/and (ii) use of pesticide while processing or stocking. The DDT and its byproducts are persisting in soil and sediments for more than 15 years and bioaccumulate in animal tissues. In this regard, DDT were banned for all uses in 49 countries and restricted to vector control in 23 countries (UNEP, 2002). 
Doi: https://doi.org/10.33002/nr2581.6853.03023

\section{Conclusions}

The study assessed the proximate compositions, heavy metal concentrations and pesticide residues in marine dried fishes collected from the Cox's Bazar, Kuakata and Dubla Island of Bangladesh coast. The proximate composition of fishes as well the moisture (11.27\% to $38.94 \%)$ and protein content $(51.33 \%$ to $77.68 \%)$ were analyzed which was almost similar to the previous studies. Among the heavy metals, the As $(8.41 \mathrm{mg} / \mathrm{kg}$ to $22.27 \mathrm{mg} / \mathrm{kg}), \mathrm{Fe}(116.85 \mathrm{mg} / \mathrm{kg}$ to $160.18 \mathrm{mg} / \mathrm{kg})$ and $\mathrm{Zn}(31.08 \mathrm{mg} / \mathrm{kg}$ to $36.74 \mathrm{mg} / \mathrm{kg})$ concentration were found higher than the permissible level for human consumption, whereas, $\mathrm{Cd}, \mathrm{Cu}$ and $\mathrm{Pb}$ were found within the permissible level in all three species. The residues of organochlorine pesticides were found within maximum residue limit. In Bangladesh, due to the lack of resources and infrastructure to implement and enforce the use of pesticides in dry fish industry is a common practice. The government should take all the necessary steps to combat the situation by implementing the legislation and improving the awareness of health issues among related people. The main market for dried fish is domestic, and its sale is highest in Chittagong division and during monsoon. However, the nutritional values of dry fish deteriorate due to the longer storage. The existence of pesticides residues in dry fishes is a matter of health concern as this poisoning has long term effect on human health. Therefore, the dry fish industries should take more precautionary steps during storage of dry fish in the warehouse and in the sales center. Increasing knowledge on dried fish as a healthy food will, hopefully, open up foreign markets and lead to increasing development to adjust this traditional food product to those markets.

\section{Acknowledgments}

Sincere appreciation to the Bangladesh Agricultural Research Council (BARC), Dhaka, Bangladesh for the financial support (BARC NATP-I, SPGR project) to carry out the chemical analysis of the study.

\section{References}

Ahmad, A.K. and Othman, S.M. (2010). Heavy metal concentrations in sediments and fish from Lake Chini, Pahang. Malaysian Journal of Biological Science, 10: 93-100.

Ako, P.A. and Salihu, S.O. (2004). Studies on some major and trace metals in smoked and ovendried fish. Journal of Applied Science and Environmental Management, 8(2): 5-9.

AOAC (Association of Official Analytical Chemists) (1995). Official Methods of the Association of Analytical Chemists, AOAC International, Washington DC, USA, $16^{\text {th }}$ edition.

Atuanya, E.I., Edefetah, M.A. and Nwogu, N.A. (2011). Microbiological qualities and some heavy metals (Mercury and Cadmium) levels of fresh and dry fish species sold in Benin City, Edo state, Nigeria. Bulletin of Environment, Pharmacology and Life Sciences, 1(1): 10-14.

Belton, B., Hossain, M.A.R., Rahman, M.M. and Thilsted, S.H. (2014). Dried fish production, consumption and trade in Bangladesh. WorldFish Bangladesh. 41 p.

Bhuiyan, M.N.H., Bhuiyan, H.R., Rahim, M., Ahmed, K., Haque, K.M.F., Hassan, M.T. and Bhuiyan, M.N.I. (2008). Screening of organochlorine insecticides (DDT and heptachlor) in dry fish available in Bangladesh. Bangladesh Journal of Pharmacology, 3(2): 114-120.

Bhuiyan, M.N.I., Bhuiyan, H.R. and Nath, K.K. (2009). Incidence of organochlorine insecticides (DDT and heptachlor) in Bangladeshi dry fish: seasonal trends and species variability. African Journal of Environmental Science and Technology, 3(11): 405-411. 
Bhuiyan, M.R. (1992). Proximate biochemical analysis and spoilage pattern of six marine fish of the Bay of Bengal. Master thesis, Institute of Marine Science and Fisheries, University of Chittagong, Chittagong. 98 p.

Chatterjee, A., Bhattacharya, B. and Das, R. (2001). Temporal and organ-specific variability of selenium in marine organism from the eastern coast of India. Advances in Environmental Research, 5: 167-174.

Chowdhury, M.A.Z., Amin-ud-Din, M., Malek, M.A. and Zaman, M.A. (2010). DDT residue and its metabolites in dried fish of Dhaka city markets. Soil and Environment, 29(2): 117-121.

Clearwater, S.J., Farag, A.M. and Meyer, J.S. (2002). Bioavailability and toxicity of diet borne copper and zinc to fish. Comparative Biochemistry and Physiology Part C. Toxicology and Pharmacology, 132: 269-313.

DoF (Department of Fisheries) (2012). National Fish Week Compendium. Department of Fisheries, Dhaka, Bangladesh, p. 144.

FAO (Food and Agriculture Organization) (1983). Compilation of legal limits for hazardous substance in fish and fishery products. Food and Agriculture Organization, Fishery Circular, 466. $100 \mathrm{p}$.

FAO/WHO (Food and Agriculture Organization/ World Health Organization) (1984). List of maximum levels recommended for contaminants by the joint FAO/ WHO Codex Alimentarius Commission, 2nd series. CAC/FAL, Rome, 3: 1-8.

Flowra, F.A., Nahar, D.G., Tumpa, A.S. and Islam, M.T. (2012). Biochemical analysis of five dried fish species of Bangladesh. University Journal of Zoology, Rajshahi University, 31: 09-11.

Lovern, J.A. (1950). Some causes of variation in the composition of fish oil. Journal of International Society of Leather Trades Chemists, 34(1): 7-21.

Mansour, S.A., Belal, M.H., Abou-Arab, A.A.K. and Gad, M.F. (2009). Monitoring of pesticides and heavy metals in cucumber fruits produced from different farming systems. Chemosphere, 75(5): 601-609.

Olowu, R.A., Ayejuyo, O.O., Adewuyi, G.O., Adejoro, I.A., Denloye, A.A.B., Babatunde, A.O. and Ogundajo, A.L. (2010). Determination of heavy metals in fish tissues, water and sediment from Epe and Badagry lagoons, Lagos, Nigeria. E- Journal Chemistry, 7(1): 215221.

Rashed, M.N. (2001). Monitoring of environmental heavy metals in fish from Nasser Lake. Environment International, 27: 27-33.

Rompala, J.M., Rutosky, F.W. and Putnam, D.J. (1984). Concentrations of environmental contaminants from selected waters in Pennsylvania. United States Fish and Wildlife Service Republic, State College, Pennsylvania, US.

Rubbi, S.F., Mujibar, M., Khan, A.R., Jahan, S.S. and Majeda, B. (1987). Proximate composition and quality of some commercial species of freshwater fish. Bangladesh Journal of Scientific Research, 5(1): 1-20.

Siddique, M.A.M. and Aktar, M. (2011). Changes of nutritional value of three marine dry fish (Johnius dussumieri, Harpodon nehereus and Lepturacanthus savala) during storage. Food and Nutrition Sciences, 2: 1082-1087.

Siddique, M.A.M. and Aktar, M. (2012). Detection of health hazard insecticide dichlorodiphenyltrichloroethane (DDT) in some common marine dry fish samples from Bangladesh. Health, 4(4): 185-189.

Tüzen, M. (2003). Determination of heavy metals in fish samples of the middle Black sea (Turkey) by graphite furnace atomic absorption spectrometry. Food Chemistry, 80(1):119-123. 
Doi: https://doi.org/10.33002/nr2581.6853.03023

UNEP (United Nations Environment Program) (2002). United Nations Environment ProgramChemicals, Indian Ocean Regional Report. UNEP Chemicals is a part of UNEP's Technol. Ind. Econ. Div., pp. 15-67.

Yi, Y., Yang, Z. and Zhang, S. (2011). Ecological risk assessment of heavy metals in sediment and human health risk assessment of heavy metal in fish in the middle and lower reaches of the Yangtze River basin. Environmental Pollution, 159: 2575-2585. 